\title{
PENGEMBANGAN BAHAN AJAR SEJARAH AFRIKA BERBASIS MULTIKULTURALISME UNTUK MAHASISWA JURUSAN PENDIDIKAN SEJARAH
}

Oleh:

\author{
Abd. Haris Nasution \\ Flores Tanjung \\ Arfan Diansyah
}

\begin{abstract}
ABSTRAK
Tujuan penelitian ini ialah untuk mengembangkan Bahan Ajar Sejarah Afrika Berbasis Multikulturalisme untuk Mahasiswa Jurusan Pendidikan Sejarah. Pengumpulan data dilakukan menggunakan angket, observasi, dan wawancara. Bahan Ajar dikembangkan mengunakan model Borg dan Gall yang dikelompokkan dalam empat tahap, yakni studi pendahuluan, pengembangan, uji lapangan, diseminasi dan sosialisasi produk. Penilaian ahli materi sebesar 4,14 yang termasuk dalam katergori baik dan penilaian ahli media sebesar 4,07 yang termasuk dalam kriteria baik. Penilaian mahasiswa dalam tahap uji lapangan terbatas, uji lapangan lebih luas, dan uji operasional masing-masing 4,$19 ; 4,26$; dan 4,14. Nilai 4,19 dalam uji lapangan termasuk dalam kriteria baik, nilai 4,26 dalam uji lapangan lebih luas termasuk dalam kriteria sangat baik, dan nilai 4,14 dalam uji operasional termasuk dalam kriteria baik.
\end{abstract}

Keywords: Bahan Ajar, Sejarah Afrika, Multiculturalisme 


\section{I.Pendahuluan}

Bahan ajar merupakan hal dasar yang harus dimiliki oleh setiap pengajar terutama Dosen. Untuk itu setiap Dosen perlu untuk melaksanakan Pengembangan bahan ajar yang mutakhir sesuai dengan karakteristik mahasiswanya. Hal ini sejalan dengan pendapat Hamid Hasan (2017) pada seminar APPS 2017, bahwa bahan ajar yang paling mutakhir ialah hasil penelitian Dosen sendiri.

Pengembangan bahan ajar dilaksanakan sebagai cara untuk mengidentifikasi, mengembangkan, dan mengevaluasi isi dan strategi pembelajaran. Selain itu, pengembangan bahan ajar mempertimbangkan sifat materi ajar, jumlah mahasiswa , dan ketersediaan materi. Pengembangan bahan ajar mengunakan prinsip luwes. Prinsip luwes artinya dapat menerima hal-hal baru yang belum tercakup dalam substansi mata kuliah pada saat pengimplementasiannya (Mbulu 2004:8). Prinsip luwes artinya, Mahasiswa mampu menerima nilai-nilai/kompetensi baru dalam mata kuliah melalui perkuliahan yang disampaikan oleh Dosen. Kompetensi tersebut dapat diwujudkan melalui proses pembelajaran yang telah ditetapkan melalui rencana pelaksanaan pembelajaran semester (RPS). Kesesuaian pelaksanaan proses pembelajaran dengan perencanaan proses pembelajaran menjadi penunjang tercapainya learning outcomes.

Dalam penelitian ini, peneliti akan mengembangkan bahan ajar Sejarah Afrika yang berbasis nilai-nilai Multikulturalisme dalam perkuliahan Sejarah Afrika di Jurusan Pendidikan Sejarah FIS UNIMED. Hal ini didasari oleh minimnya ketersediaan literature tentang Sejarah Afrika. Adapun literature-literatur yang beredar dipasaran hanyalah literature-literatur yang bersifat Grand Narrative, yang miskin akan nilai (valueless) dan cenderung berisi narasi tentang sebab-akibat saja. Padahal konten materi Sejarah Afrika sangat sarat akan nilai-nilai Multikulturalisme yang potensial untuk diinternalisasikan dalam diri Mahasiswa, terlebih ditengah-tengah gencarnya issue SARA dan etnisitas dewasa ini.

Materi Perkuliahan Sejarah Afrika sarat akan nilai-nilai Multikulturalisme. Multikulturalisme merupakan nilai yang diwujudkan dengan perilaku menerima, menghormati dan terbuka terhadap perbedaan budaya, perilaku dan keyakinan dari 
masyarakat lintas etnis. (Banks, 1961:2). Internalisasi nilai-nilai multikulturalisme dapat mencegah disintegrasi bangsa dari konflik terkecil, misalnya memudarkan stereotype-stereotipe terhadap budaya dan warna kulit tertentu. Oleh karenanya, nilai tersebut sangat urgent untuk ditumbuh kembangkan melalui kegiatan pembelajaran.

Mata kuliah Sejarah Afrika berisikan materi-materi tentang asal-usul nenek moyang manusia, peradaban-peradaban besar Dunia hingga peranan Bangsa Afrika dalam percaturan Politik Dunia Internasional. Materi-materi tersebut banyak didukung oleh hasil penelitian dan teori-teori baru, misalnya teori Out of Africa yang menguatkan bukti bahwa seluruh manusia di Bumi merupakan migrasi dari manusia Afrika Terdahulu. Teori ini diperkuat dengan adanya pengujian DNA yang dilakukan oleh Tim Unit Identifikasi DNA Forensik Lembaga Biologi Molekuler Eijkman yang menemukan adanya kesamaan DNA antara manusia Indonesia dengan manusia dari daratan Asia dan Afrika. Hasil pengkajian Budaya yang dilakukan oleh Balai Arkeologi Sumatera Utara juga mengemukakan adanya kesamaan Budaya manusiamanusia yang berasal dari Asia-Afrika tersebut. (Semnas Asal-usul Genetika Nenek Moyang Bangsa Indonesia, 2019). Hasil penelitian tersebut tentunya sangat relevan jika dikembangkan kedalam bentuk bahan ajar Sejarah Afrika berbasis Multikulturalisme, sehingga turut menanamkan semangat Multikulturalisme dan Kebhinekaan mulai dari lingkup terkecil, yaitu kelas hingga ke masyarakat. Oleh karena itu, penelitian Pengembangan Bahan Ajar Sejarah Afrika Berbasis Multikulturalisme untuk Mahasiswa Jurusan Pendidikan Sejarah sangat penting untuk dilakukan.

\section{Pembahasan}

Hasil studi pendahuluan di Kelas B Reguler 2018 menunjukkan bahwa metode pembelajaran yang paling umum dilakukan dosen adalah menggunakan metode konvensional sehingga membuat mahasiswa cepat bosan. Selain itu penggunaan sumber belajar dalam pembelajaran terbatas pada literature-literatur grand narrative. Penyajian materi dalam literature grand narative dinilai masih belum mampu 
mengangkat motivasi belajar mahasiswa karena penyajian materi yang lewat bahasa kausalitas yang panjang kurang disukai mahasiswa. Padahal secara empirik mahasiswa cenderung menyukai buku ajar yang berisi materi-materi kekinian, yang penuh akan dimensi kontrekstual dan dapat terinternaliasasi dalam bentuk sikap. (Daryanto, 2010: 129).

Materi-materi dalam perkuliahan sejarah afrika merupakan materi yang dinilai kurang diminati oleh mahasiswa. Mahasiswa menganggap materi ini banyak mengandung unsur hafalan dan tidak kontekstual, dan materi yang harus dipelajari cukup banyak. Salah satu pokok bahasan yang dianggap sulit oleh mahasiswa adalah tentang Asal-usul bangsa Afrika dan Teori Out Of Africa. Dalam pokok bahasan tersebut cukup banyak peristiwa-peristiwa penting dan tanggal penting yang harus dihafal oleh mahasiswa. Akibat banyaknya materi yang harus dihafal, mahasiswa menjadi merasa malas mempelajari materi. Mahasiswa masih sering kesulitan untuk meraih nilai dalam materi-materi tersebut. Menurut dosen, pencapaian nilai mahasiswa untuk materi tersebut juga masih kurang memuaskan.

Masalah-masalah dalam pembelajaran untuk materi Asal-usul bangsa Afrika dan Teori Out of Africa dapat diatasi apabila materi disajikan dalam bentuk yang menarik dan kekinian. Dengan penyajian materi yang menarik dan kekinian dapat menimbulkan perasaan senang dalam diri mahasiswa untuk belajar sehingga penyampaian materi dan penanaman nilai dapat berjalan maksimal. Hal tersebut sesuai dengan pendapat Peter Kline (Angkowo dan Kosasih, 2007: 49) yang menyatakan bahwa belajar akan efektif apabila dilakukan dalam suasana yang menyenangkan ( $f u n$ and enjoy). Apabila mahasiswa memiliki minat yang tinggi untuk belajar, tentu materi pembelajaran yang disampaikan akan lebih mudah diserap oleh mahasiswa.

Pengembangan produk dilakukan dengan melakukan analisis tujuan dalam pengembangan produk bahan ajar sejarah afrika berbasis multikulturalisme, analisis kemampuan, melaksanakan prosedur pengembangan serta melakukan validasi ahli. Tujuan yang ingin dicapai dalam pengembangan bahan ajar ini adalah menghasilkan produk bahan ajar sejarah afrika berbasis multikulturalisme yang layak untuk 
pembelajaran materi Asal-usul Bangsa Afrika dan Teori Out Of Africa. Produk Bahan Ajar yang dikembangkan diharapkan mampu meningkatkan motivasi dan membantu belajar mahasiswa.

Pengembangan materi dalam produk bahan ajar diambil dari berbagai sumber kemudian dirangkum dalam sebuah produk. Penyajian materi dalam bahan ajar disusun dalam narasi teks yang bermuatan nilai-nilai multikulturalisme.

Tahap selanjutnya setelah dilakukan penyusunan bahan ajar adalah validasi produk oleh ahli materi dan ahli media yang sudah berpengalaman di bidangnya. Penilaian dari segi materi mengacu pada aspek pertimbangan isi yang terdiri dari kesesuaian kurikulum, kelayakan isi, dan cara penyajiaan. Aspek penilaian tersebut mengacu pada pendapat Hartono Kasmadi (dalam Rohani, 1997:30-33) yang menyatakan bahwa salah satu hal yang perlu dipertimbangkan dalam pengembangan bahan ajar adalah mengenai pertimbangan isi.

Sementara itu penilaian dari segi media meliputi aspek kriteria produksi, desain visual dan kualitas teknis. Aspek penilaian tersebut mengacu pada pendapat Hartono Kasmadi (dalam Rohani, 1997: 30-33) yang menyatakan bahwa dalam pemilihan dan pengembangan media aspek yang perlu diperhatikan meliputi pertimbangan produksi, peserta didik, isi, dan dosen. Aspek desain visual yang dinilai mencakup unsur-unsur visual yang dinyatakan Rohani (1997: 20-25) yakni kesederhanaan, keterpaduan, penekanan, keseimbangan, garis, bentuk, ruang, tekstur, dan warna. Dalam pendapat lain Setyosari (Sa'dun Akbar dan Hadi Sriwiyana, 2011: 216-217) menyatakan bahwa pemilihan media harus memperhatikan kesesuaian media dengan tujuan pembelajaran, kesesuaian media dengan karakteristik pembelajar, kesesuaian media dengan lingkungan belajar, kemudahan dan keterlaksanaan pemanfaatan media, dapat menjadi sumber belajar, efisiensi media dalam kaitannya dengan waktu, tenaga dan biaya, keamanan bagi pembelajar, kemampuan media dalam mengaktifkan mahasiswa, kemampuan media dalam mengembangkan suasana belajar yang menyenangkan, serta kualitas media. Penilaian aspek kualitas teknis meliputi kemampuan media memotivasi 
mahasiswa, mempermudah mahasiswa mengingat materi, penyajian media membuat materi lebih menarik serta kemudahan media digunakan.

Berdasarkan hasil analisis data pada hasil validasi ahli materi yang dilakukan dalam dua tahap dengan sekali revisi, diperoleh skor rata-rata 3,95 pada penilaian tahap pertama dan 4,14 pada penilaian tahap kedua. Rata-rata skor penialian ahli materi yang diperoleh produk bahan ajar yang dikembangkan tersebut termasuk dalam kriteria “baik' menurut pedoman konversi data kuantitatif ke data kualitatif (Eko Putro Widoyoko, 2009: 238). Sesuai dengan ketentuan penelitian bahwa produk bahan ajar dikatakan layak apabila skor rata-rata minimal termasuk kriteria baik, maka bahan ajar yang dikembangkan telah layak dari segi isi materi. Kelayakan bahan ajar didukung pernyataan ahli materi bahwa produk bahan ajar telah layak diujicobakan dari segi materi.

Penilaian ahli materi didasarkan pada kriteria pertimbangan isi materi. Pertimbangan isi terdiri dari indikator kesesuaian kurikulum, kebenaran isi, dan cara penyajian. Apabila dianalisis lebih lanjut, skor penilaian ahli materi dijabarkan dalam tabel berikut.

Tabel 1. Hasil Penilaian Ahli Materi untuk Masing-masing Kriteria

\begin{tabular}{|c|c|c|}
\hline Kriteria & Jumlah Butir & Skor Rata-rata \\
\hline Pertimbangan Isi & 22 & 4,00 \\
\hline
\end{tabular}

Tabel 2. Analisis Hasil Penilaian Ahli Materi per-Indikator

\begin{tabular}{|l|l|c|c|c|}
\hline \multicolumn{1}{|c|}{ Kriteria } & \multicolumn{1}{|c|}{ Indikator } & $\begin{array}{c}\text { Jumlah } \\
\text { Butir }\end{array}$ & Nomor Butir & $\begin{array}{c}\text { Skor Rata- } \\
\text { rata }\end{array}$ \\
\hline \multirow{2}{*}{$\begin{array}{l}\text { Pertimbangan } \\
\text { Isi }\end{array}$} & $\begin{array}{l}\text { Kesesuaian } \\
\text { Kurikulum }\end{array}$ & 3 & $1,2,3$ & 4,00 \\
\cline { 2 - 5 } & Kebenaran isi & 5 & $4,5,6,7,8$ & 4,00 \\
\cline { 2 - 5 } & $\begin{array}{l}\text { Cara } \\
\text { penyajian }\end{array}$ & 14 & $\begin{array}{c}9,10,11,12,13, \\
14,15,16,17,18, \\
19,20,21,22\end{array}$ & 4,21 \\
& \multicolumn{2}{|l}{} \\
\cline { 2 - 5 } & Rata-rata penilaian keseluruhan & $\mathbf{4 , 1 4}$ \\
\hline
\end{tabular}


Produk Bahan Ajar yang dikembangkan telah sesuai dengan kurikulum, indikator pembelajaran yang diambil. Bahan Ajar yang dikembangkan sudah baik dilihat dari indikator kesesuaian kurikulum dengan skor rata-rata 4,00. Dilihat dari indikator kebenaran isi, materi dalam media komik sudah baik dengan skor rata-rata 4,00. Kebenaran isi mencakup kronologisasi, muatan nilai dan peran para tokoh dalam media produk bahan ajar sudah baik.

Selanjutnya dilihat untuk indikator cara penyajian materi, dengan skor perolehan rata-rata 4,21 menunjukkan bahwa bahan ajar sudah sangat baik. Produk bahan ajar yang dikembangkan mampu menyajikan materi lebih konkret, penyajian materi runtut, dapat membantu mahasiswa memahami materi, membantu mahasiswa mengingat materi, muatan nilai multikulturalisme sudah sesuai dengan indikator.

Sedangkan validasi ahli media dilakukan dalam tiga tahap, dengan dua kali revisi. Rata-rata skor yang diperoleh secara berturut-turut 2,82, 3,80, dan 4,07. Ratarata skor yang diperoleh pada penilaian tahap pertama menurut pedoman konversi data kuantitatif ke kualitatif (Eko Putro Widoyoko, 2009: 238) termasuk dalam kriteria "cukup". Sementara rata-rata skor yang diperoleh pada penilaian tahap kedua dan ketiga termasuk dalam kategori "baik". Sesuaidengan ketentuan penelitian bahwa produk bahan ajar dikatakan layak apabila skor rata-rata minimal termasuk kriteria baik, maka bahan ajar yang dikembangkan telah layak dari segi pertimbangan media.

Penilaian ahli media dilakukan berdasarkan kriteria produksi, desain visual dan kualitas teknis. Masing-masing kriteria dilihat dari berbagai indikator. Analisis lebih lanjut penilaian hasil validasi ahli materi dapat dilihat pada tabel berikut.

Tabel 3. Hasil Penilaian Ahli Media untuk Masing-masing Kriteria

\begin{tabular}{|c|c|c|}
\hline Kriteria & $\begin{array}{c}\text { Jumlah } \\
\text { Butir }\end{array}$ & $\begin{array}{c}\text { Skor Rata- } \\
\text { rata }\end{array}$ \\
\hline Kriteria Produksi & 8 & 4,12 \\
\hline Desain Visual & 16 & 4,00 \\
\hline Kualitas Teknis & 4 & 4,20 \\
\hline
\end{tabular}


Tabel 4. Analisis Hasil Penilaian Ahli Media Per- Indikator

\begin{tabular}{|l|l|c|c|c|}
\hline \multicolumn{1}{|c|}{ Kriteria } & Indikator & $\begin{array}{c}\text { Jumlah } \\
\text { Butir }\end{array}$ & $\begin{array}{c}\text { Nomor } \\
\text { Butir }\end{array}$ & $\begin{array}{c}\text { Skor } \\
\text { Rata- } \\
\text { rata }\end{array}$ \\
\hline \multirow{2}{*}{$\begin{array}{l}\text { Kriteria } \\
\text { Produksi }\end{array}$} & Kondisi Fisik & 2 & 1,2 & 4,00 \\
\cline { 2 - 5 } & Kualitas Bahan & 4 & $3,4,5,6$ & 4,00 \\
\cline { 2 - 5 } & Emotion Impact & 2 & 7,8 & 4,50 \\
\hline $\begin{array}{l}\text { Desain } \\
\text { Visual }\end{array}$ & $\begin{array}{l}\text { Prinsip visual } \\
\text { desain sampul }\end{array}$ & 4 & $9,10,11,12$ & 4,00 \\
\cline { 2 - 5 } & $\begin{array}{l}\text { Prinsip visual } \\
\text { ilustrasi isi cerita }\end{array}$ & 4 & $\begin{array}{c}13,14,15,1 \\
6\end{array}$ & 4,00 \\
\cline { 2 - 5 } & $\begin{array}{l}\text { Prinsip visual } \\
\text { rangkuman } \\
\text { sejarah }\end{array}$ & 4 & $\begin{array}{c}17,18,19,2 \\
0\end{array}$ & 4,00 \\
\cline { 2 - 6 } & $\begin{array}{l}\text { Prinsip visual } \\
\text { ilustrasi tokoh- } \\
\text { tokoh sejarah }\end{array}$ & 4 & $21,22,23,2$ & 4,00 \\
\hline \multirow{2}{*}{$\begin{array}{l}\text { Kualitas } \\
\text { Teknis }\end{array}$} & $\begin{array}{l}\text { Syarat media } \\
\text { yang baik }\end{array}$ & 4 & $25,26,27,2$ & 4,20 \\
\hline & Rata-rata skor keseluruhan & & \\
\hline
\end{tabular}

Secara umum berdasarkan kriteria produksi (butir penilaian nomor 1-8) bahan ajar yang dikembangkan memperoleh skor rata-rata 4,12 termasuk kategori baik. Kondisi fisik bahan ajar sudah baik dengan skor rata-rata 4,00. Kondisi fisik dinilai dari aspek ukuran dan bentuk serta kepraktisan bahan ajar. Kualitas bahan ajar sudah baik dengan perolehan skor rata-rata 4,00. Adapun aspek yang dinilai dalam indikator kualitas bahan terdiri dari kemudahan bahan diperoleh, keamanan bahan, kualitas cetak, serta daya tahan bahan. Selanjutnya indikator emotion impact produk bahan ajar memperoleh rata-rata skor 4,50 yang berarti sudah sangat baik. Bahan ajar yang dikembangkan mengandung nilai estetika dan mampu membuat belajar mahasiswa lebih menyenangkan.

Berdasarkan kriteria desain visual (butir penilaian nomor 9-24), maka produk bahan ajar yang dikembangkan telah memenuhi prinsip desain visual dengan skor 4,00. 
Indikator prinsip desain visual sampul, isi materi maupun kandungan nilai multikulturalisme memperoleh skor rata-rata 4,00 yang termasuk dalam kriteria baik. Prinsip desain visual yang dinilai mencakup butir penilaian mengenai tata letak, pilihan warna, kesesuaian gambar, serta jenis dan ukuran huruf.

Selanjutnya secara kualitas teknis dengan indikator syarat bahan ajar yang baik, produk bahan ajar termasuk kriteria baik dengan skor perolehan 4,20. Butir penilaian syarat bahan ajar yang baik meliputi kemampuan memotivasi mahasiswa, mempermudah mahasiswa mengingat, membuat penyajian materi menarik serta efektifitas dalam proses internalisasi nilai.

Produk bahan ajar yang telah mendapat rekomendasi layak dari ahli materi maupun ahli media sudah memenuhi syarat untuk diujicobakan di lapangan. Rata-rata skor perolehan pada tahap uji lapangan terbatas, uji lapangan lebih luas dan uji operasional secara berturut-turut 4,19, 4,26 dan 4,14 dengan kategori baik, sangat baik, dan baik. Hasil analisis perolehan skor penilaian siswa untuk setiap kriteria dan indikator dijabarkan dalam tabel di bawah ini.

Tabel 5. Hasil Penilaian Uji Lapangan untuk Masing-masing Kriteria

\begin{tabular}{|l|c|c|c|c|}
\hline \multirow{2}{*}{ Kriteria } & Jumlah & \multicolumn{3}{|c|}{ Skor Rata-rata Uji Lapangan } \\
\cline { 2 - 5 } & Butir & Terbatas & Lebih Luas & Operasional \\
\hline $\begin{array}{l}\text { Segi Penyajian } \\
\text { Materi }\end{array}$ & 8 & 4,28 & 4,17 & 4,11 \\
\hline $\begin{array}{l}\text { Segi Penyajian } \\
\text { Media }\end{array}$ & 16 & 4,14 & 4,31 & 4,15 \\
\hline
\end{tabular}

Tabel 6. Analisis Hasil Penilaian Mahasiswa dalam Uji Lapangan per-Indikator

\begin{tabular}{|c|c|c|c|c|c|c|}
\hline \multirow[t]{2}{*}{ Kriteria } & \multirow[t]{2}{*}{ Indikator } & \multirow{2}{*}{$\begin{array}{c}\text { Jumlah } \\
\text { Butir }\end{array}$} & \multirow{2}{*}{$\begin{array}{c}\text { Nomor } \\
\text { Butir }\end{array}$} & \multicolumn{3}{|c|}{ Skor Rata-rata Uji Lapangan } \\
\hline & & & & Terbatas & $\begin{array}{c}\text { Lebih } \\
\text { Luas }\end{array}$ & Operasional \\
\hline \multirow{3}{*}{$\begin{array}{l}\text { Segi } \\
\text { Penyajian } \\
\text { Materi }\end{array}$} & $\begin{array}{l}\text { Ketertarikan } \\
\text { Materi }\end{array}$ & 2 & 1,2 & 4,33 & 4,08 & 3,97 \\
\hline & $\begin{array}{l}\text { Manfaat untuk } \\
\text { mahasiswa }\end{array}$ & 1 & 3 & 4,00 & 4,17 & 4,16 \\
\hline & Kontekstual & 1 & 4 & 3,67 & 4,50 & 4,21 \\
\hline
\end{tabular}




\begin{tabular}{|c|c|c|c|c|c|c|}
\hline & $\begin{array}{l}\text { Rangkuman } \\
\text { Materi }\end{array}$ & 1 & 5 & 5,00 & 4,17 & 4,26 \\
\hline & $\begin{array}{l}\text { Penggunaan } \\
\text { Bahasa }\end{array}$ & 1 & 6 & 4,33 & 4,00 & 4,11 \\
\hline \multirow{8}{*}{$\begin{array}{l}\text { Segi } \\
\text { Penyajian } \\
\text { Media }\end{array}$} & $\begin{array}{l}\text { Bentuk dan } \\
\text { Ukuran }\end{array}$ & 2 & 7,8 & 4,16 & 4,25 & 3,94 \\
\hline & $\begin{array}{l}\text { Kemudahan } \\
\text { penggunaan }\end{array}$ & 1 & 9 & 4,33 & 4,67 & 4,16 \\
\hline & Pilihan warna & 1 & 10 & 4,33 & 4,17 & 4,37 \\
\hline & $\begin{array}{l}\text { Penggunaan } \\
\text { huruf }\end{array}$ & 1 & 11 & 3,67 & 4,33 & 4,32 \\
\hline & $\begin{array}{l}\text { Ilustrasi } \\
\text { Gambar }\end{array}$ & 1 & 12 & 3,67 & 4,50 & 4,11 \\
\hline & Isi materi & 2 & 13,14 & 3,67 & 4,00 & 4,16 \\
\hline & $\begin{array}{l}\text { Kegunaan } \\
\text { media }\end{array}$ & 3 & $15,16,17$ & 4,44 & 4,22 & 4,14 \\
\hline & Kualitas teknis & 1 & 18 & 4,33 & 4,83 & 4,26 \\
\hline \multicolumn{4}{|c|}{ Rata-rata Skor Keseluruhan } & 4,19 & 4,26 & 4,14 \\
\hline
\end{tabular}

Hasil penilaian mahasiswa untuk segi penyajian materi (butir penilaian mahasiswa nomor 1-6) pada uji terbatas memperoleh skor rata-rata 4,28 berarti penyajian materi dalam bahan ajar yang dikembangkan sangat baik. Adapun indikator yang dinilai meliputi kemenarikan bahan ajar, manfaat untuk mahasiswa, materi kontekstual, rangkuman materi dan penggunaan bahasa dengan skor masing-masing 4,$33 ; 4,00 ; 3,67 ; 5,00 ;$ dan 4,33. Sementara untuk segi penyajian bahan ajar (butir penilaian siswa nomor 7-18) memperoleh rata-rata skor 4,14 berarti bahan ajar yang dikembangakan sudah baik. Indikator penilaian meliputi bentuk dan ukuran, kemudahan penggunaan, pilihan warna, penggunaan huruf, ilustrasi gambar, isi materi bahan ajar, kegunaan bahan ajar, serta kualitas teknik dengan skor masing-masing 4,16; 4,$33 ; 4,33 ; 3,67 ; 3,67 ; 3,67 ; 4,44 ;$ dan 4,33 .

Hasil penilaian mahasiswa untuk segi penyajian materi (butir penilaian mahasiswa nomor 1-6) pada uji luas memperoleh skor rata-rata 4,17 berarti bahan ajar yang dikembangkan sudah baik. Indikator yang dinilai meliputi kemenarikan bahan ajar, manfaat untuk mahasiswa, materi kontekstual, rangkuman materi dan penggunaan 
bahasa dengan skor masing-masing 4,08; 4,17; 4,50; 4,17; dan 4,00. Sementara untuk segi penyajian bahan ajar (butir penilaian mahasiswa nomor 7-18) memperoleh skor 4,31 berarti produk bahan ajar yang dikembangakan sudah sangat baik. Indikator penilaian meliputi bentuk dan ukuran, kemudahan penggunaan, pilihan warna, penggunaan huruf, ilustrasi gambar, isi materi, kegunaan bahan ajar, serta kualitas teknik dengan skor masing-masing 4,25; 4,67; 4,17; 4,33; 4,50;4,00;4,22; dan 4,83.

Hasil penilaian mahasiswa untuk segi penyajian materi (butir soal nomor 1-6) pada uji operasional memperoleh skor rata-rata 4,11 berarti bahan ajar yang dikembangkan sudah baik. Indikator yang dinilai meliputi kemenarikan bahan ajar, manfaat untuk mahasiswa, materi kontekstual, rangkuman materi dan penggunaan bahasa dengan skor masing-masing 3,97; 4,16; 4,21; 4,26; dan 4,11. Sementara untuk segi penyajian bahan ajar (butir penilaian mahasiswa nomor 7-18) memperoleh skor 4,15 berarti bahan yang dikembangakan sudah baik. Indikator penilaian meliputi bentuk dan ukuran, kemudahan penggunaan, pilihan warna, penggunaan huruf, ilustrasi gambar, isi materi, kegunaan bahan ajar, serta kualitas teknik dengan skor masingmasing.Dengan hasil perolehan skor demikian maka produk bahan ajar sudah layak dari dari segi penilaian mahasiswa dengan megacu pada ketentuan bahwa bahan ajar dinyatakan layak apabila perhitungan skor minimal termasuk pada kriteria baik.

Hasil observasi yang dilakukan pada ketiga tahap uji lapangan menunjukkan bahwa produk bahan ajar yang dikembangkan dalam tahap uji coba terlihat mampu menarik minat mahasiswa untuk membaca bahan ajar tersebut. Setelah bahan ajar dibagikan kepada mahasiswa, nampak mahasiswa antusias membaca bahan ajar tersebut. Ketertarikan mahasiswa terhadap bahan ajar merupakan gejala yang baik untuk meningkatkan prestasi belajar mahasiswa. Awalnya mahasiswa merasa kurang tertarik terhadap materi sejarah afrika karena dianggap membosankan dan tidak kontekstual. Bahan Ajar yang dikembangkan disini dapat berperan sebagai alternatif sumber belajar mahasiswa yang lebih menarik dibandingkan dengan hanya membaca literature grand narrative sehingga melalui bahan ajar ini mahasiswa memiliki alternatif sumber belajar lain disamping literature-literatur yang biasa mereka gunakan. Dari 
ketiga tahap uji coba lapangan tersebut, tidak dilakukan proses revisi terhadap produk bahan ajar yang dikembangkan. Selama uji coba lapangan dilaksanakan tidak ditemukan kendala yang berarti sehingga mengaharuskan dilakukan revisi. Hal ini sejalah dengan pendapat Sugiyono (2010: 426) bahwa revisi produk dilakukan apabila terdapat kekurangan dan kelemahan.

\section{Referensi}

Banks, A. James (1961). Multicultural Education; Issues and Perspectives.Wiley: University of Washington.

Borg, W. R. \& Gall, M. D. (2003). Educational research, New York: Allyn \& Bacon Hamid Hasan, Said (2017). Pendidikan Sejarah Untuk Membangun Manusia Baru Indonesia. Jurnal Mimbar Pendidikan Vol.20 No.1.

Hasan, Said Hamid, "Kurikulum Berbasis Kompetensi Berdasarkan SK Mendiknas 232/U/2000 dan Alternatif Pemecahannya", Seminar Nasional di Universitas Negeri Yogyakarta (UNY), 11 Mei 2002.

Mbulu Joseph. 2001. Pengajaran Individual. Malang: Penerbit Yayasan Elang Mas.

Prastowo, Andi. 2011. Panduan Kreatif Membuat Bahan Ajar Inovatif. Yogyakarta: Diva Press.

Said Hamid Hasan. (2011). Kurikulum dan Tujuan Pendidikan. Bandung: Rizki Press

Sugiono. (2010). Metode penelitian kualitatif, kuantitatif dan R\&D. Bandung: Alfabeta.

Supardi. (2005). Pendidikan Multikulturalisme. Yogyakarta: UII Press

Syaodih Nana Sukmadinata. (2013).Metode Penelitian Pendidikan.Bandung: PT RemajaRosdakarya

Wasino. (2010). Pembelajaran IPS Dalam Realita Di Era KTSP: Studi Eksplorasi Pelaksanaan Pembelajaran IPS Pada SMP Di Kabupaten Pati. Paramita Vol. 20 No. 2. Hlm. 179. 